\title{
Measuring the incidence of social factors on scientific research: A socio-scientometrics analysis of strategic countries
}

\author{
Barbara S. Lancho-Barrantes* \\ Francisco J. Cantu-Ortiz ${ }^{\star *}$
}

Artículo recibido:

1 de noviembre de 2019

Artículo aceptado:

30 de marzo de 2020

Artículo de investigación

\section{AbStract}

Throughout scientific literature, some studies have examined the positive impact of research in society. However, this paper is oriented in the opposite direction analyzing how social factors could be influencing scientific results. The research sample comprises Mexico and its 18 strategic partners in science and technology and a 17-year temporary window. The results are divided into three parts, the first one shows the relation among population, government investment in tertiary education, gross domestic expenditure on R\&D (GERD) (as a percentage of Gross Domestic Product (GDP)) number of researchers with scientific production and citations received. The second part is focused on the relationship between researcher mobility (sedentary or migratory:

* University of Leeds, United Kingdom

** Tecnológico de Monterrey, México

b.s.lancho-barrantes@leeds.ac.uk fcantu@tec.mx

INVESTIGACIÓN BIBLIOTECOLÓGICA, vol. 34, núm. 85, octubre/diciembre, 2020, México, ISSN: 2448-8321 pp. 61-80 
inflow, outflow, transitory) and scientific collaboration. The third part analyses whether the countries research preferences (measured through the Relative Activity Index in subject areas) have a repercussion on scientific production. This study facilitates a better understanding of social contributions to the scientific and socioeconomic development of countries and it is valuable for governments and policy makers for taking into account the importance of these social variables in leading countries towards excellence in science.

Keywords: Scientific Production; Social Factors; Science Policy; Bibliometrics

Midiendo la influencia de los factores sociales en la investigación científica: un análisis sociocienciométrico de países estratégicos

Barbara S. Lancho-Barrantes y Francisco J. Cantu-Ortiz

\section{RESUMEN}

En la literatura científica algunos estudios han examinado el impacto positivo que tiene la investigación en la sociedad. Sin embargo, este trabajo analiza cómo los factores sociales pueden influir en los resultados científicos. La muestra de investigación estudia a México y sus socios estratégicos en ciencia y tecnología. Los resultados se dividen en tres partes, la primera muestra la relación entre población, inversión pública en educación superior, gasto interno bruto en I+D (GERD) (como porcentaje del Producto Interno Bruto (PIB)), número de investigadores y los resultados científicos (producción científica y citas recibidas). La segunda parte se centra en la relación entre la movilidad del investigador (sedentario o migratorio (flujos de entrada y salida, estancias transitorias)) y la producción en colaboración. La tercera parte analiza si las preferencias en investigación de los países tienen una repercusión en el conjunto total de la producción científica. Este estudio facilita una mejor comprensión de las contribuciones sociales al desarrollo científico y socioeconómico de los países y es útil para que los gobiernos y los responsables políticos tengan en cuenta la importancia de estas variables sociales y, como resultado, conducir a los países hacia la excelencia en ciencia.

Palabras clave: Producción Científica; Factores Sociales; Política Científica; Bibliometría 


\section{INTRODUCTION}

R esearch plays a fundamental and essential role in our society. This has Rproportioned enormous benefits to population such as facing its own challenges, improving the quality of people's lives, innovating or discovering new tools to make a world healthier, eliminating or fighting powerful diseases and reaching unimaginable scientific processes. For all these reasons, scientific results generate a considerable and significant impact on our society (Bornmann, 2012).

The National Science Foundation (NSF) created the Broader Impacts to evaluate not only the intellectual significance of a planned research, but also the potential societal benefits of this research contributing to reach the desired societal outcomes. According to an official document from National Science Board (NSB) the criteria for reviewing research proposals should include not only quality requirements of scientific outputs but also measure the broadest contribution to reach global social challenges (NSB, 2011).

Some authors have analyzed the social effects of science (Spaapen and van Drooge, 2011; Owen, Macnaghten, and Stilgoe, 2012; Marmolejo-Leyva, Perez-Angon, and Russell, 2015; Samuel and Derrick, 2015; Derrick and Samuel, 2016; Hill, 2016; Bozeman and Youtie, 2017). Many countries have worked under the principle "science is the genie that keeps the country competitive, but the genie needs to be fed" (Stephan, 2012: 10; Bornmann, 2013). Moreover some studies have revealed a significant relationship between scientific results and global economy (Inglesi-Lotz, Chang, and Gupta, 2015; Kumar, Stauvermann, and Patel, 2016).

Apart from the recognized positive effects that science provides to society some authors have assessed the effects that social factors are causing on research. They have stated the positive relationship between inputs (i.e., economic funding, political efforts, human resources in R\&D) and outputs (i.e., generated scientific results) (Moya-Anegon and Herrero-Solana, 1999; Gonzalez-Brambila et al., 2016).

Although social components have a close relationship with the economy they refer to a broader structure composed by all factors that interfere in society. This structure is composed about factors such as population density, specific characteristics, cultural identity, composition, migratory movements and other elements that involve a society in general.

After contextualizing the present study, our intention is to measure the influence of some social dimensions together on research results. For this, we chose a representative sample that attended to different social characteristics and a wide time-window. For this reason, we chose a closed sample of 19 
strategic countries (Mexico and its strategic partners) where there is a country representation from each world region. We decided to study this sample because it is mixture of countries with cultural diversity (Lancho-Barrantes and Cantú-Ortiz, 2019).

In this paper, we measure the relationship that exists between the social variables and research results: population of the country, gross domestic expenditure on R\&D (GERD) and economic investment in tertiary education as a percentage of GDP, researchers, researcher's migratory movements, social networks and collaboration, publication in academic disciplines, scientific production and citations as a measure of the research representation. The results of this work can assist countries to redesign their policies in science to achieve a greater scientific productivity.

We formulate the following research questions based on the above mentioned:

Which kind of correlations exist among population, expenditure in research, investment in tertiary education, researchers, and scientific production and citations in all countries? Which countries produce more documents per researcher? Do the different types of researcher's mobility have any relationship with scientific collaboration? How is the country's contribution to different scientific disciplines? Is there any kind of relation among all these results?

The main hypothesis in this study is that social dimensions (expenditure in research, investment in tertiary education, researchers, researcher's mobility, scientific collaboration, disciplines patterns) have a correlation with scientific results. Therefore, social variables are interconnected and have an influence on research.

\section{Materials and Methods}

In order to develop this study, we have selected a closed sample of countries with cultural, social, geographic, linguistic, and economic differences to give a wide-ranging spectrum from worldwide sources. For this reason, we chose Mexico and its strategic partners because this is a diverse sample of 19 countries all very different from each other.

The selected countries are the following: Argentina, Brazil, Canada, Chile, China, Colombia, France, Germany, India, Israel, Japan, Russian Federation, South Africa, South Korea, Spain, Turkey, United Kingdom and United States considered strategic in Science, Technology and Innovation for Mexico (Conacyt, 2016). 
We used data from UNESCO Institute for Statistics (UIS) as a main data source because it provides a wide range of indicators (http://uis.unesco.org/, 2018).

With the purpose of extracting data of different patterns of researcher' mobility we used World of Research 2015. Revealing patterns and archetypes in scientific research. The book contains over 70 national profiles and comprises general statistics and graphs along with analyses and interpretations (Elsevier Analytical Services, 2015).

In order to extract the countries' scientific production, we used Scopus database because it represents the overall structure of world science at a global scale. Furthermore, we used SciVal to extract the total number of citations received.

The time window for our study comprise 17 years. Data from 1996 to 2012 for: investment on tertiary education, gross domestic expenditure on $R \& D$ (GERD) as a percentage of GDP and researchers (FTE). The time frame for scientific production and citations cover from 1999 to 2015. We displaced the data by three years because the economic and social effect on scientific results are not materialized immediately. For instance, the effect of GERD/GDP investment on scientific production takes at least three years to manifest. We determined the three-year displacement period by experimenting with several time windows.

We downloaded data from Scopus, SciVal, and UNESCO in March 10, 2017. The variables extracted from UNESCO are:

- Gross domestic expenditure on RED (GERD) as a percentage of GDP is the total intramural expenditure on $\mathrm{R} \& \mathrm{D}$ performed in the national territory during a specific reference period expressed as a percentage of GDP of the national territory.

- Government expenditure on tertiary education as a percentage of GDP: Total general (local, regional and central) government expenditure on tertiary education (current, capital, and transfers), expressed as a percentage of GDP. It includes expenditure funded by transfers from international sources to government.

- Total population by country: Estimated midyear population from each country.

- Researchers (FTE): Number of professionals engaged in the conception or creation of new knowledge during a given year at full-time equivalent (FTE). 
From Scopus database and SciVal we have extracted:

- Scientific production: Total number of documents produced by the countries (from 1999 to 2015).

- Scientific production of different subject areas: Number of documents produced each year from the temporary window (from 1999 to 2015) by the countries in the 27 Scopus subject areas.

In order to know the relative effort that a country of analysis devotes to a specific field measured in publications we applied RAI (Relative Activity In$d e x$ ). We decided to use relative indicators that may prove rather useful in the comparative assessment of scientists, groups, institutions or countries (Schubert and Braun, 1986).

RAI (Relative Activity Index) is calculated by dividing the share of a country's output in a particular field relative to the share of the world's output in that same field. It therefore represents how concentrated a country's output is in a particular area relative to the world average and can be used to estimate specialization in a particular field. A value of 1.0 indicates that a country's research activity in a field corresponds exactly with the global activity in that field; higher than 1.0 implies a greater emphasis while lower than 1.0 suggests a lesser focus.

- Citations: Number of citations by the documents published during the source year, $-i$.e. citations in years $X, X+1, X+2, X+3 \ldots$ to documents published during year $\mathrm{X}$.

We have divided the scientific production between the different types of scientific collaboration. A publication is considered collaborative when there is more than one author in the authorship byline in Scopus. The four types of scientific collaboration are (Leimu and Koricheva, 2005):

- International collaboration: Defined as at least two different countries listed in the authorship byline.

- National collaboration: Defined at least two different institutions listed in the authorship byline, all of which are from the same country.

- Institutional collaboration: Defined at least two authors listed in the authorship byline, all of which are affiliated with the same institution.

- Single authorship: These are technically not collaboration. This is defined as documents written by only one author listed in the authorship byline. 
We have downloaded researcher' mobility data from the book World of Research 2015 (Elsevier Analytical Services, 2015):

\section{Migratory}

Outflow: Researchers whose Scopus author data indicates that they first published with an affiliation in Country X and have subsequently migrated from Country $\mathrm{X}$ to another country (or countries) for at least two years without returning to Country X.

Inflow: Researchers whose Scopus author data indicates that they migrated to Country X from another country (or countries) for at least two years without leaving Country X.

\section{Transitory}

Researchers whose Scopus author data indicates that they are based in Country $\mathrm{X}$ for less than two years at a time but are predominantly based in another country (or countries).

\section{Sedentary}

Researchers whose Scopus author data indicates that they have not published with an affiliation outside of Country X.

\section{Results and Discussion}

We have calculated correlations among expenditure in research, investment in tertiary education, researchers and scientific results. The second part is focused on migratory movements and collaboration and the last part dedicated to countries preferences in research.

As we can observe in Table 1, all the variables have a high correlation with the scientific production. The population (0.747), the researchers (0.793), the investment in education (0.529) and the investment in research (0.663).

The highest correlation is between researchers and scientific production. It seems that if the number of researchers increases, scientific production increases as well. 


\begin{tabular}{|c|c|c|c|c|c|c|}
\hline & Population & Researchers & $\begin{array}{l}\text { Government } \\
\text { expenditure } \\
\text { on tertiary } \\
\text { education as } \\
\text { a percentage } \\
\text { of GDP }\end{array}$ & $\begin{array}{l}\text { Gross domestic } \\
\text { expenditure on } \\
\text { R\&D (GERD) as } \\
\text { a percentage } \\
\text { of GDP }\end{array}$ & $\begin{array}{c}\text { Scientific } \\
\text { production }\end{array}$ & Citations \\
\hline Population & 1 & & & & & \\
\hline Researchers & 0.786 & 1 & & & & \\
\hline $\begin{array}{l}\text { Government } \\
\text { expenditure } \\
\text { on tertiary } \\
\text { education as } \\
\text { a percentage } \\
\text { of GDP }\end{array}$ & 0.409 & 0.470 & 1 & & & \\
\hline $\begin{array}{l}\text { Gross domestic } \\
\text { expenditure on } \\
\text { R\&D (GERD) as } \\
\text { a percentage } \\
\text { of GDP }\end{array}$ & 0.491 & 0.599 & 0.384 & 1 & & \\
\hline $\begin{array}{l}\text { Scientific } \\
\text { production }\end{array}$ & 0.747 & 0.793 & 0.529 & 0.663 & 1 & \\
\hline Citations & -0.121 & -0.217 & -0.502 & -0.289 & -0.330 & 1 \\
\hline
\end{tabular}

Table 1. Correlation among social factors and scientific results for all countries in the 17-temporary frame

\section{Researcher's mobility and scientific collaboration}

In order to determine the relationship between researcher's mobility and scientific collaboration we show the Table 2 with scientific production divided into four groups of collaboration. Additionally, with the different types of mobility: Migratory (Inflow, Outflow, Transitory) and Sedentary.

As we can observe, countries produce more in International collaboration and in Institutional collaboration than in National collaboration or even Single authorship. Chile, Colombia and France are the countries with the highest percentage of international collaboration for their production.

Furthermore, India, China and Turkey are the countries with the highest percentage of Institutional collaboration. However, there are countries that have almost equal the international and institutional percentages: Argentina, Japan, and Mexico. 


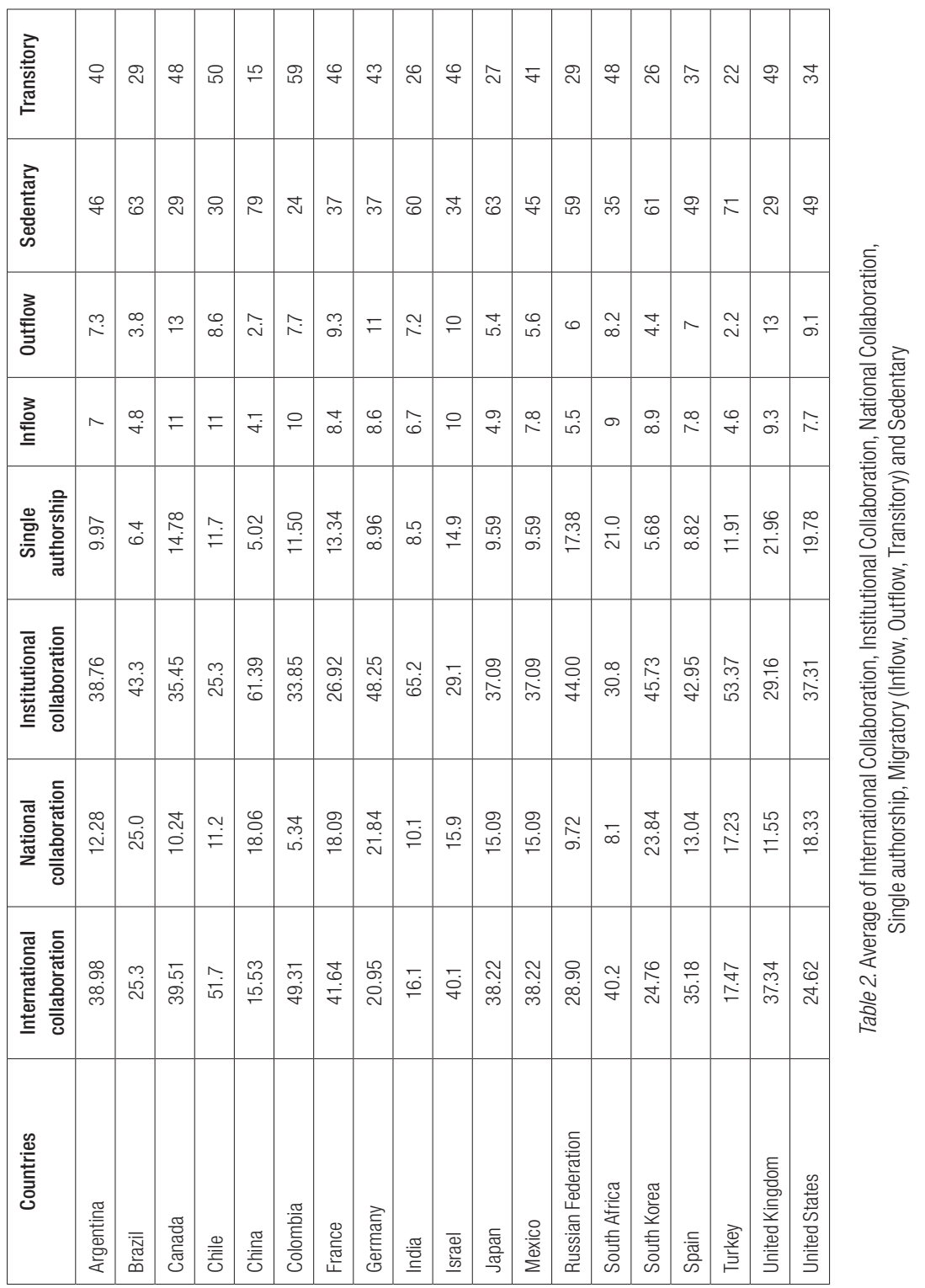


Respect to the researcher's mobility relative to migratory movements (Inflow, Outflow, Transitory) or sedentary manners, the countries with the highest migration tendencies are Colombia, Canada, and the United Kingdom. In the case of Colombia, the transitory percentage is higher than the others.

On the contrary countries with the highest percentage of sedentary researchers are China, Turkey and Brazil. They are countries with a low percentage of International collaboration.

Canada has a high transitory pattern of researchers. We can observe that Canada has low correlation between researchers and investment in tertiary education possibly because many of them are not permanently resident in the country.

In order to know if there is some kind of correlation between the collaboration indicators and mobility patterns indicators, the Pearson correlation matrix is shown (Table 3).

Predictably, there is a high correlation between the Transitory indicator and the international scientific collaboration of $r=0.821$ for all countries. The data of institutional collaboration has a correlation of 0.767 with the sedentary indicator. There is a correlation of 0.849 between the Inflow and Transitory data. Also, correlation of 0.766 between Inflow and Outflow.

The correlation between the Single authorship percentage and Outflow has a correlation of 0.596 . And a correlation of 0.750 between Transitory and Outflow, the indicators most linked to the scientific diaspora.

This may indicate that the movements of the countries favor collaboration and therefore, thanks to this, the quality of the work and production increase remarkably. The countries that have a high percentage of international collaboration and that have high percentages of transitory researchers are the countries that publish more documents per researcher and which receive more citations per researcher.

\section{Do countries specialize in particular research areas?}

In this part of the work we focus on the contribution that countries make to scientific production by areas. First, we know the area where more documents are published, and then through the RAI (Relative Activity Index) we measure how is the country's contribution to the whole scientific production.

In the Table 4, we can observe the subject areas which produce the large number of documents in the range of years studied. 


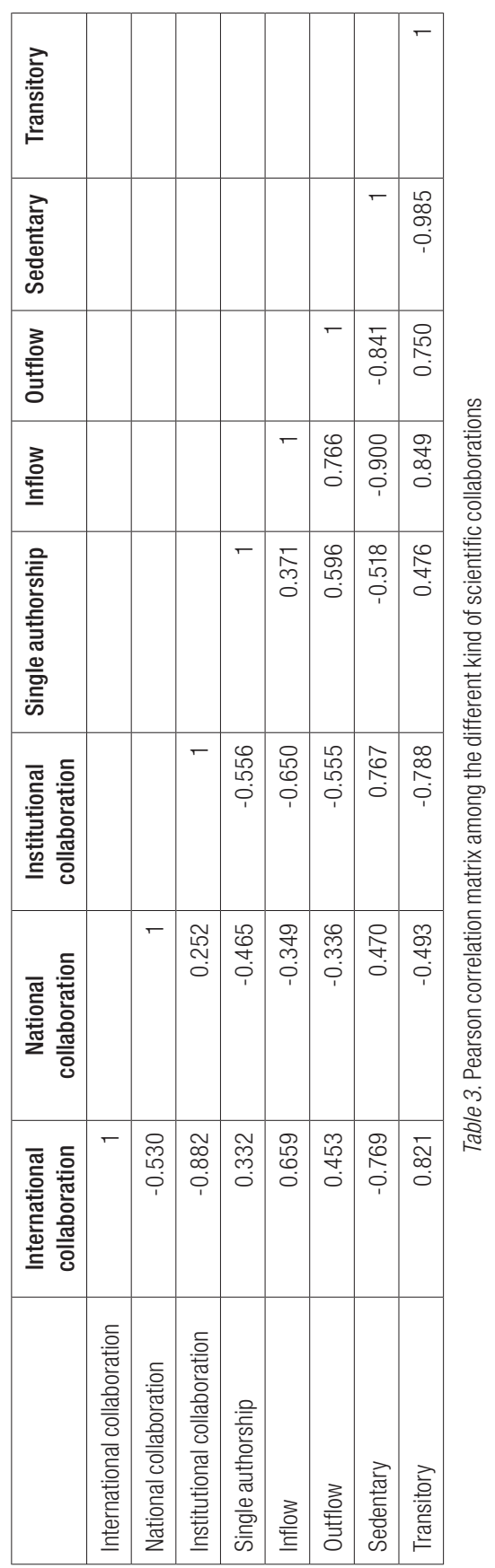




\begin{tabular}{|c|c|c|c|c|}
\hline Countries & $\begin{array}{c}\text { Subject area } \\
\text { with greatest } \\
\text { production }\end{array}$ & $\begin{array}{l}\text { Percentage from } \\
\text { total production }\end{array}$ & $\begin{array}{l}\text { Citations to } \\
\text { subject area } \\
\text { with greatest } \\
\text { production }\end{array}$ & $\begin{array}{c}\text { Percentage } \\
\text { from total } \\
\text { citations }\end{array}$ \\
\hline Argentina & $\begin{array}{c}\text { Medicine } \\
37,492\end{array}$ & 25.09 & 673,303 & 29.34 \\
\hline Brazil & $\begin{array}{c}\text { Medicine } \\
184,130\end{array}$ & 28.17 & $2,556,404$ & 33.05 \\
\hline Canada & $\begin{array}{l}\text { Medicine } \\
368,856\end{array}$ & 29.29 & $11,020,671$ & 37.45 \\
\hline Chile & $\begin{array}{l}\text { Medicine } \\
23,447\end{array}$ & 23.71 & 366,423 & 23.97 \\
\hline China & $\begin{array}{c}\text { Engineering } \\
1,483,903\end{array}$ & 36.78 & $7,845,710$ & 21.66 \\
\hline Colombia & $\begin{array}{c}\text { Medicine } \\
16,724\end{array}$ & 27.22 & 240,541 & 36.02 \\
\hline France & $\begin{array}{l}\text { Medicine } \\
424,972\end{array}$ & 27.45 & $9,808,600$ & 31 \\
\hline Germany & $\begin{array}{l}\text { Medicine } \\
624,808\end{array}$ & 28.52 & $14,139,252$ & 30.69 \\
\hline India & $\begin{array}{l}\text { Medicine } \\
224,432\end{array}$ & 20.82 & $2,115,344$ & 19.16 \\
\hline Israel & $\begin{array}{c}\text { Medicine } \\
81,740\end{array}$ & 30.11 & $2,124,925$ & 32.85 \\
\hline Japan & $\begin{array}{l}\text { Medicine } \\
525,662\end{array}$ & 26.19 & $9,230,700$ & 28.54 \\
\hline Mexico & $\begin{array}{c}\text { Medicine } \\
48,952\end{array}$ & 21.95 & 719,973 & 25.72 \\
\hline Russian Federation & $\begin{array}{c}\text { Physics and } \\
\text { Astronomy } \\
244,594\end{array}$ & 35.28 & $2,416,339$ & 43.93 \\
\hline South Africa & $\begin{array}{c}\text { Medicine } \\
44,664\end{array}$ & 24.49 & 933,361 & 34.85 \\
\hline South Korea & $\begin{array}{l}\text { Engineering } \\
229,949\end{array}$ & 28.64 & $2,227,598$ & 19.96 \\
\hline Spain & $\begin{array}{l}\text { Medicine } \\
299,511\end{array}$ & 30.15 & $5,426,788$ & 30.25 \\
\hline Turkey & $\begin{array}{l}\text { Medicine } \\
178,098\end{array}$ & 42 & $1,595,810$ & 35 \\
\hline United Kingdom & $\begin{array}{l}\text { Medicine } \\
780,372\end{array}$ & 31.60 & $21,180,242$ & 36.78 \\
\hline United States & $\begin{array}{l}\text { Medicine } \\
2,705,199\end{array}$ & 31.15 & $77,768,163$ & 34.95 \\
\hline
\end{tabular}


Observing the Table 4 Medicine is the area which has the highest production in all countries except China, South Korea and the Russian Federation.

Countries which produce the most documents in this area (in proportion to their total production) are: Turkey, United Kingdom, and United States. With regard to citations, the countries that receive more citations in the area of Medicine with respect to total citations are: Canada, United Kingdom, Colombia, Turkey, and United States.

Engineering is the chosen area for China to publish the majority of its works, however China does not receive as many citations to the documents in this area. The citation habits vary by different subject areas, for example Medicine receives far more citations than other disciplines.

The Russian Federation publishes most of its papers in Physics and Astronomy. However, Russia receives more citations in this area than other countries in Medicine. We must remember that the research in Physics in Russia is one of the most important in the world, in fact, Russia does not have Medicine among its first three disciplines to publish.

In South Korea as in China, the preferred area for its production is Engineering but it does not receive many citations in comparison with other areas.

Once we know which is the discipline chosen to publish by countries, we detect what the contribution of each country to total world production by disciplines. For this we apply RAI (Relative Activity Index) defined in methodology part (Elsevier Analytical Services, 2015).

The formula of this indicator is applied to the sample of production downloaded by 27 scientific disciplines for the 19 countries and in the 17-year time window. When the indicator is less than 1 , the contribution made by the country is less than that of the discipline to total production, if the indicator is equal to 1 the contribution of that country is equal to that of the discipline and if it is greater than 1 this country contributes more to the discipline than what the discipline does in general.

Those countries that on average contribute with a higher value to all disciplines are the United States, United Kingdom and China. On the contrary with the lowest values are Colombia, Chile, and Argentina. The results show that the United States is the country with the greatest contribution in all disciplines except in Material Science where China is the highest contributor.

At first glance, countries contributions performed to disciplines are less than the contribution than the discipline performs to total production. Except in certain disciplines where the contribution of certain countries is very remarkable. For example, in the area of Engineering where only USA exceeds 1 . China is near to 1 with 0.963 . Medicine is the area chosen by almost all countries to publish. The most contributing countries in this area are United States, United Kingdom and Germany. 


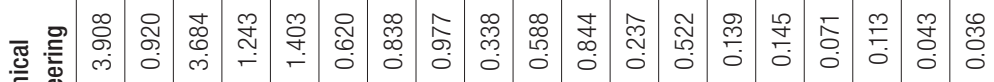
这 言

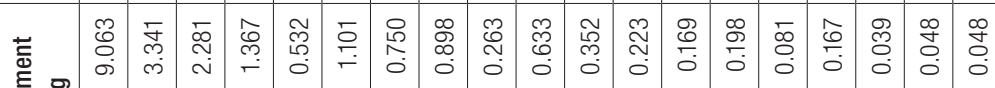

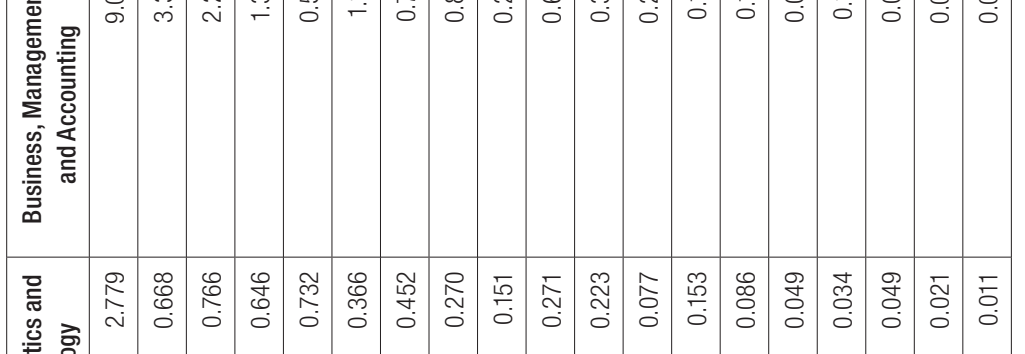

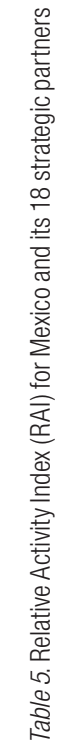

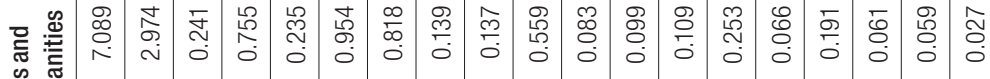
妾密

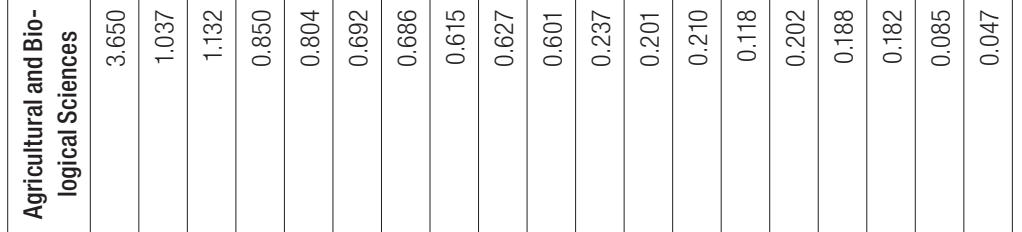

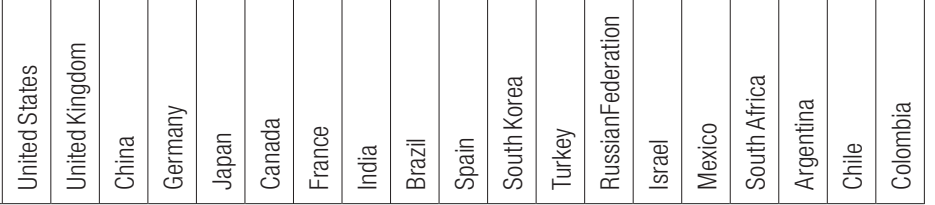




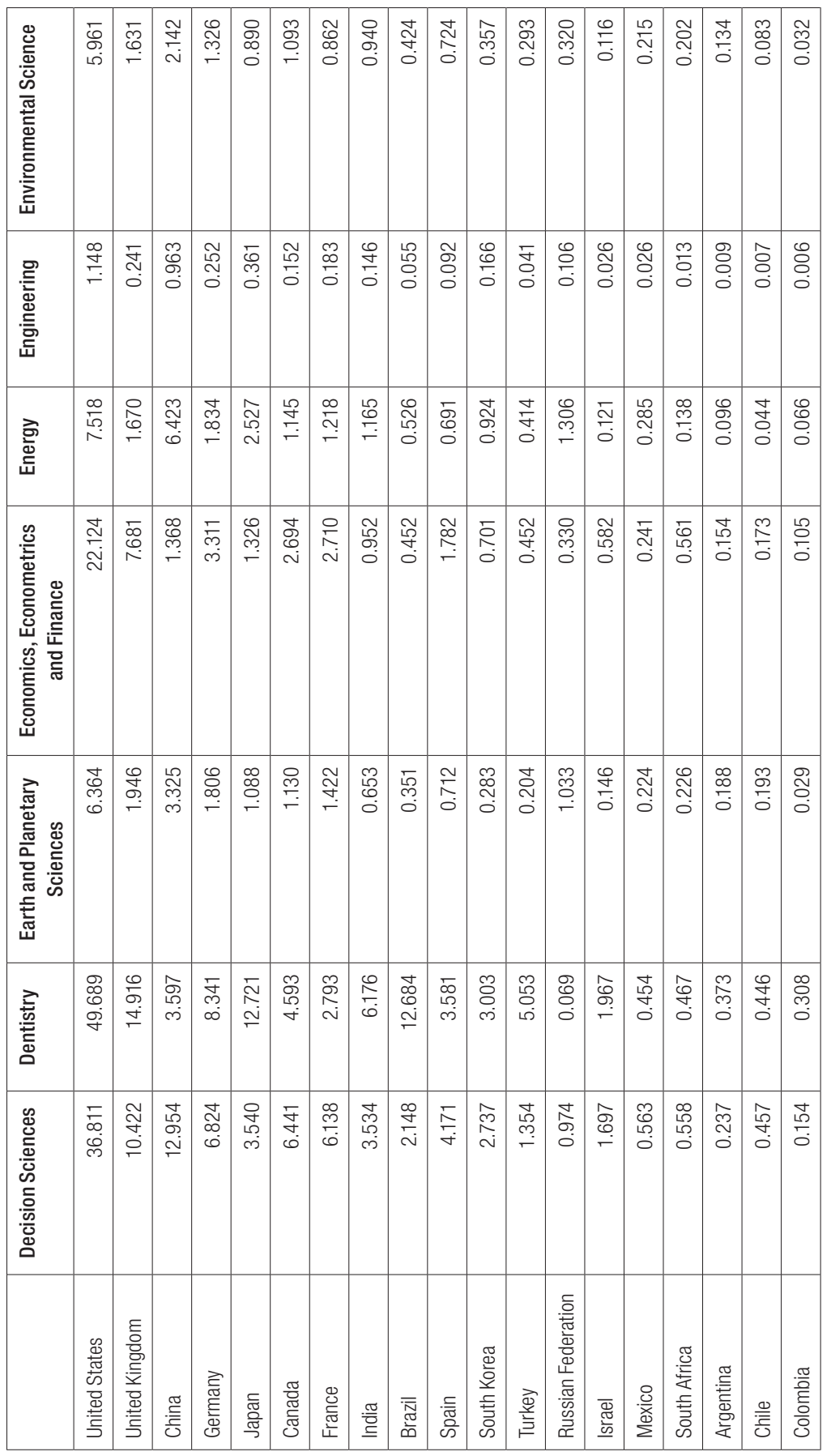




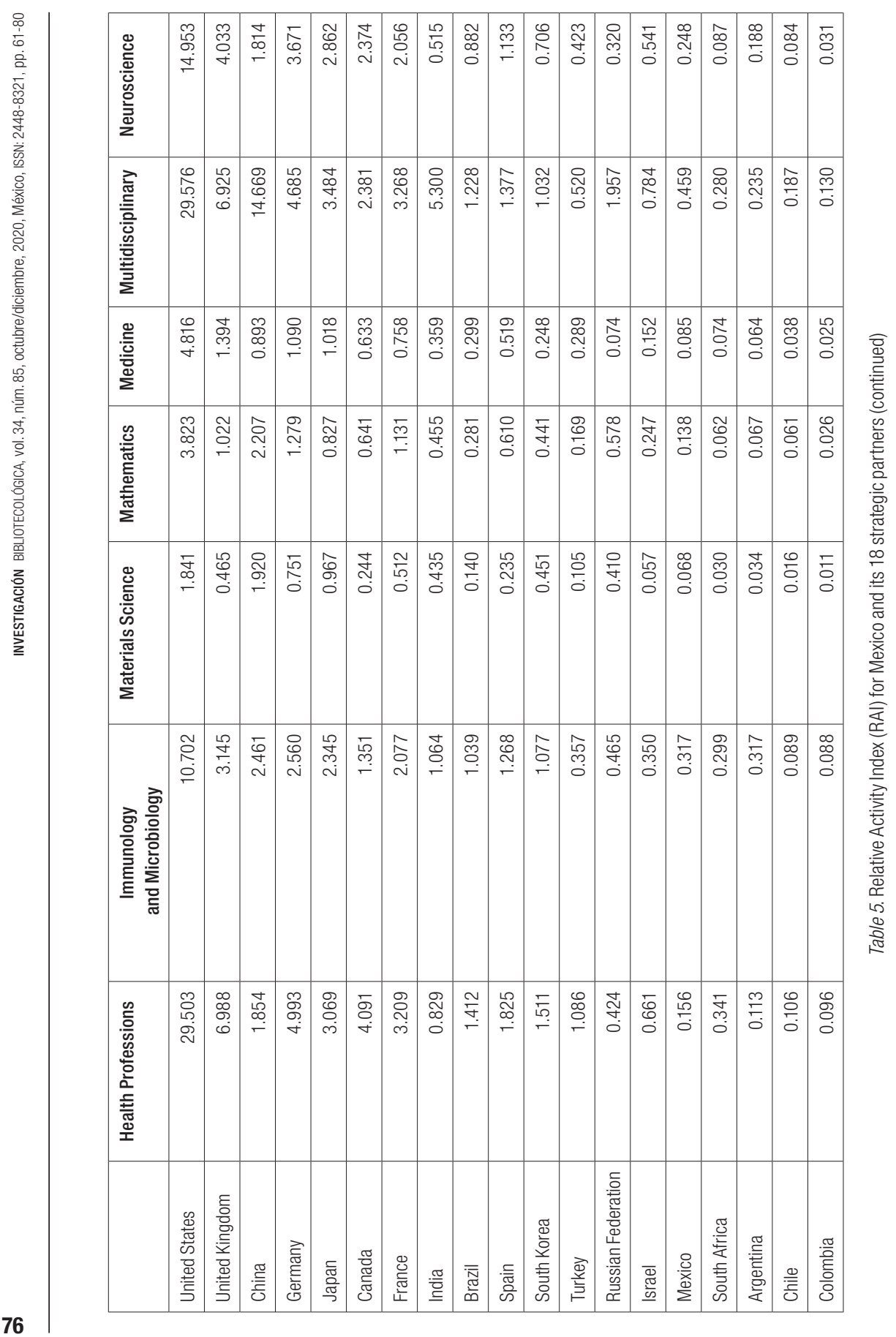




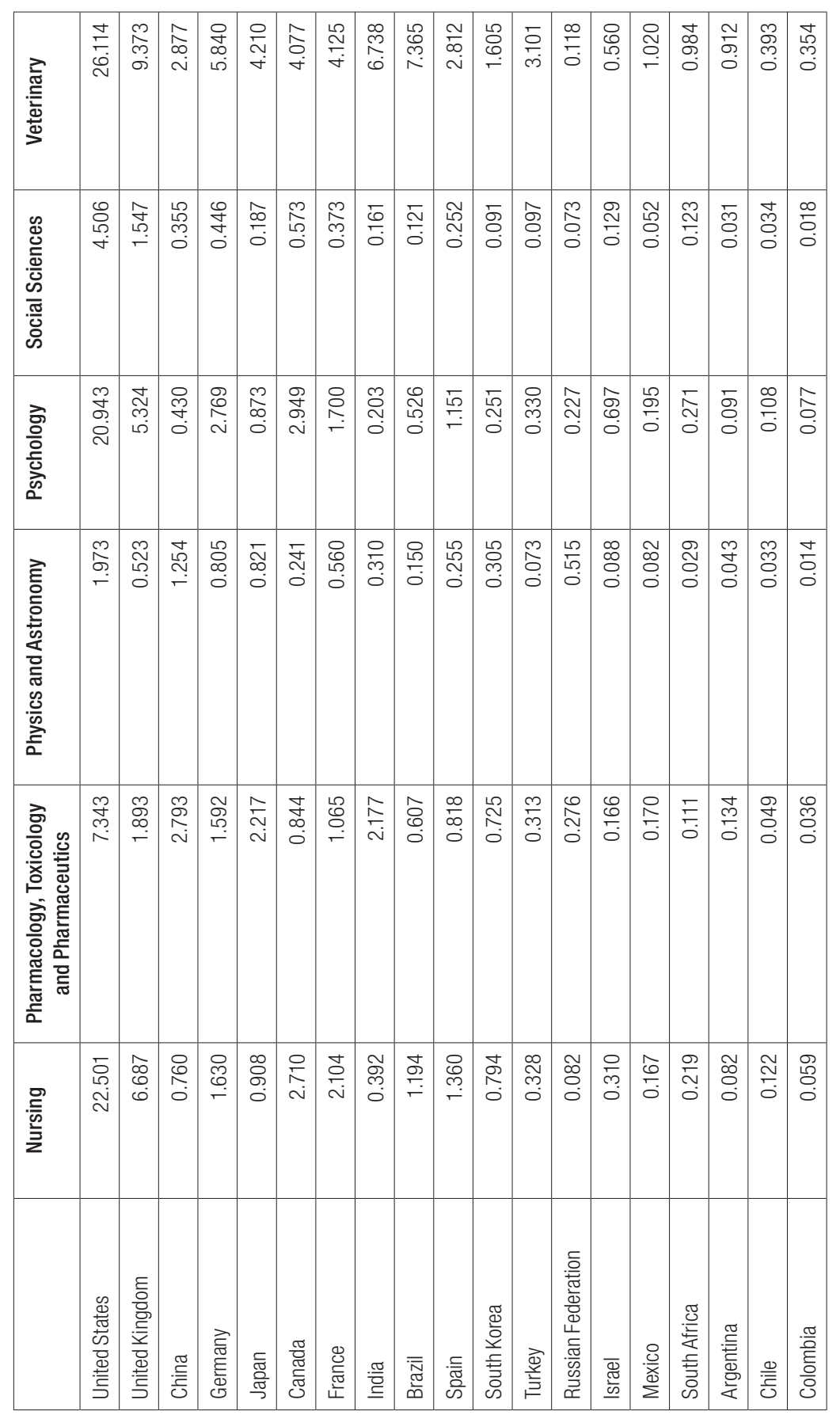


This study contributes to the analysis of the incidence of social variables into scientific research in a sample of countries of diverse nature. There are 18 countries defined as Mexico's strategic partners by National Science and Technology Council (Conacyt), the decentralized public agency of the federal public administration responsible for the development of science and technology policies in Mexico. These countries are designated in terms of cooperation, alliances, and common projects with Mexico (Conacyt, 2016).

It has been shown that on average there is a high correlation between social variables (population, researchers, investment in tertiary education, investment in research) and scientific production. In the case of citations, it is not possible to appreciate or demonstrate linearity with current data because of curvilinear function of citations. However, there are countries in which some social variables have little correlation with scientific production.

With respect to the mobility values of researchers, the sample is also divided into the countries with the highest percentage of Sedentary and the countries with the highest percentage of Migratory tendencies. China, Turkey and Brazil are the most sedentary. The countries (ranked) that are the most migratory are Colombia, Canada, and United Kingdom.

There is a high correlation between the values of Transitory and International Collaboration, and between Sedentary and Institutional Collaboration. There is also high correlation between Inflow and Outflow.

Scientific collaboration favors production and if there is a correlation between the researcher's international movements and scientific collaboration this has a positive effect on scientific production.

The scientific discipline where most researchers publish is Medicine. Except the case of China and South Korea in which is Engineering and the Russian Federation which is Physical Sciences. These disciplines are those that have a greater percentage of the production of the country and are those that increase production with its greater contribution.

The highest values of RAI average for all the areas are the United States, United Kingdom and China. The lowest ones correspond to Colombia, Chile, and Argentina. In all disciplines, the United States is the country that has the greatest contribution, except in Material Sciences, in which China is the first.

Finally, the main contribution of this study is the high relation of a selected set of social variables on the country's research production. Moreover, mobility patterns of researchers have a correlation with scientific collaboration, and therefore, this in turn on the increase of total production. The 
vocation of a country measured by priority areas also impacts on research through the contribution that each country establishes.

This study should help governments to be aware of how these social variables affect research and take part in this matter. An analysis of economic and scientific results relations can help the government of a country to promote research in their countries to strengthen their research ecosystems to give light to scientific policies.

\section{REFERENCES}

BIE (Bureau of Industry Economics). 1996. Performance from published papers. Canberra: BIE, Australian Science.

Bornmann, Lutz. 2012. "Measuring the societal impact of research: Research is less and less assessed on scientific impact alone-we should aim to quantify the increasingly important contributions of science to society". EMBO Reports 13 (8): $673-676$. https://doi.org/10.1038/embor.2012.99

Bornmann, Lutz. 2013. "What is societal impact of research and how can it be assessed? a literature survey”. Journal of the American Society for Information Science and Technology 64 (2): 217-233. https://doi.org/10.1002/asi.22803

Bozeman, Barry and Jan Youtie. 2017. "Socio-economic impacts and public value of government-funded research: Lessons from four US national science foundation initiatives." Research Policy 46 (8): 1387-1398. https://doi.org/10.1016/j.respol.2017.06.003

Conacyt (Consejo Nacional de Ciencia y Tecnología). 2016. National general report of science, technology and innovation. Accessed 9 December 2019. http:/www.siicyt.gob.mx/index.php/transparencia/informes-conacyt/informe-general-del-estado-de-la-ciencia-tecnologia-e-innovacion/informe-general-2016

Derrick, Gemma E. and Gabrielle N. Samuel. 2016. "The evaluation scale: Exploring decisions about societal impact in peer review panels." Minerva 54 (1): 75-97. https://doi.org/10.1007/s11024-016-9290-0

Elsevier Analytical Services. 2015. World of Research 2015. Amsterdam: Elsevier Analytical Services.

Gonzalez-Brambila, Claudia N., Leonardo Reyes-Gonzalez, Francisco Veloso, and Miguel Angel Perez-Angón. 2016. "The Scientific Impact of Developing Nations." PLOS ONE 11 (3). https://doi.org/10.1371/journal.pone.0151328

Hill, Steven. 2016. "Assessing (for) impact: future assessment of the societal impact of research.” Palgrave Communications 2. https://doi.org/10.1057/palcomms.2016.73

Inglesi-Lotz, Roula, Tsangyao Chang and Rangan Gupta. 2015. "Causality between research output and economic growth in BRICS”. Quality \& Quantity 49 (1): 167-176. https://doi.org/10.1007/s11135-013-9980-8 
Kumar, Ronald Ravinesh, Peter Josef Stauvermann, Arvind Patel. 2016. "Exploring the link between research and economic growth: an empirical study of China and USA.” Quality \& Quantity 50 (3): 1073-1091.

https://doi.org/10.1007/s11135-015-0191-3

Lancho-Barrantes, Barbara and Francisco Cantú-Ortiz. 2019. "Science in Mexico: A Bibliometric Analysis." Scientometrics 118 (2): 499-517.

https://doi.org/10.1007/s11192-018-2985-2

Leimu, Roosa and Julia Koricheva. 2005. "Does scientific collaboration increase the impact of ecological articles?" Bio Science 55: 438-443. https://doi.org/10.1641/0006-3568(2005)055[0438:DSCITI]2.0.CO;2

Marmolejo-Leyva, Rafael, Miguel Angel Perez-Angon, and Jane M. Russell. 2015. "Mobility and International Collaboration: Case of the Mexican Scientific Diaspora." PLOS ONE 10 (6). https://doi.org/10.1371/journal.pone.0126720

Moya-Anegon, Felix and Victor Herrero-Solana. 1999. "Science in America Latina: A comparison of bibliometric and scientific-technical indicators". Scientometrics 46 (2): 299-320. https://doi.org/10.1007/BF02464780

NSB (National Science Board). 2011. National Science Foundation's Merit Review Criteria: Review and Revisions. Washington, DC: National Science Board.

Owen, Richard, Phil Macnaghten and Jack Stilgoe. 2012. "Responsible research and innovation: From science in society to science for society, with society". Science and Public Policy 39 (6): 751-760. https://doi.org/10.1093/scipol/scs093

Samuel, Gabrielle N. and Gemma E. Derrick. 2015. "Societal impact evaluation: Exploring evaluator perceptions of the characterization of impact under the REF2014." Research Evaluation 24 (3): 229-241. https://doi.org/10.1093/reseval/rvv007

Schubert, Andras and Tibor Braun. 1986. "Relative indicators and relational charts for comparative assessment of publication output and citation impact”. Scientometrics 9: 281-291.

https://doi.org/10.1007/BF02017249

Spaapen, Jack and Leonie van Drooge. 2011. "Introducing "productive interactions" in social impact assessment”. Research Evaluation 20 (3): 211-218. https://doi.org/10.3152/095820211X12941371876742

Stephan, Paula. 2012. How economics shapes science. Cambridge, MA: Harvard University Press.

Para citar este texto:

Lancho-Barrantes, Barbara S. and Francisco J. Cantu-Ortiz. 2020. "Measuring the incidence of social factors on scientific research: A socio-scientometrics analysis of strategic countries". Investigación Bibliotecológica: archivonomía, bibliotecología e información 34 (85): 61-80. http://dx.doi.org/10.22201/iibi.24488321xe.2020.85.58211 